\title{
Annular S' Velocity
}

National Cancer Institute

\section{Source}

National Cancer Institute. Annular S'Velocity. NCI Thesaurus. Code C139045.

The peak velocity of the annular motion during ventricular systole. 